\title{
Research on the anti-Plugging Property of Permeable Concrete Pavement
}

\author{
Dong Liu , Xia Liu, Weiwei Han, Jing Chen \\ China West Construction Group Southwest Co., Ltd., Chengdu, China
}

\begin{abstract}
Permeable concrete pavement is a kind of porous road, which can allow rainwater to penetrate into the ground and maintain the recyclability of water resources. However, with constantly using, its voids may be blocked with the impurities in the rainwater, such as leaves, silt, etc. If that happens, the permeable function of the permeable concrete pavement will be affected. In this paper, the different structure of the permeable concrete pavement is studied, including the variation trend of the coefficient of permeability in the simulated plugging and the recovery rate of the permeable concrete pavement after cleaning and dredging. The results show that the upper small size coarse aggregate (4.75 mm to $9.5 \mathrm{~mm}$ ) structure of the porous concrete is conducive to filter out most of the impurities, and it will reinforce the resistance to blocking of permeable concrete. But, it is not easy to recover after blockage, if the upper small size coarse aggregate is too thick. The anti-blocking performance and post-blocking recovery rate of permeable concrete are better, when the upper layer thickness is $15 \mathrm{~mm}$.
\end{abstract}

\section{Introduction}

With the promotion of urban construction, the proportion of impervious pavement has been rising constantly. Ordinary concrete pavement consists mainly of proportional cementitious materials (organic, inorganic and organic-inorganic combination), granular aggregate, water, chemical admixtures and mineral admixtures. Ordinary concrete pavement brings convenience to people, which has greatly improved people's living standard and production efficiency, however, [1] this kind of pavement is impervious, and surface flow is hard to penetrate, causing flooding in urban areas. Moreover, the air permeability of ordinary concrete pavement is poor, which is not convenient for heat exchange. When the sun irradiates the ground, the temperature of the earth will rise, and it will lead to urban heat island effect and urban environment deterioration.

Compared with ordinary concrete, the preparation of permeable concrete reduces or [2] avoids the use of fine aggregate, forming intercommunicating pore microstructure. The porous structure of permeable concrete makes the pavement have good permeable performance, and the rain can seep into the ground quickly, which can effectively reduce or eliminate flood disasters caused by urban rainstorms. However, the surface runoff produced by rainfall contains a large number of suspended particles that can flow into the porous structure of permeable concrete pavement along with the water continually, leading to the decrease of permeability, shortened service life of permeable concrete pavement and increasing the occurrence of flood and freeze-thaw disasters in cities. Several measures had been proposed such as infiltration, retention, storage, purification, usage and discharge, and these would guide the promotion of sponge city construction in future.

Compared with conventional concrete, the strength and structure performance of permeable concrete are more variable, which mainly depends on the porosity. According to some literatures, [3] the porosity factors of permeable concrete pavement usually vary among $15 \%$ to $25 \%$, and the permeability coefficients mostly range from $2 \mathrm{~mm} / \mathrm{s}$ to $6 \mathrm{~mm} / \mathrm{s}$, but some of them even reach $10 \mathrm{~mm} / \mathrm{s}$. The pores in permeable concrete pavement can be blocked by suspended particles, such as sediment and debris in surface runoff produced by rainfall, leading to the reduction of permeability and shortened service life of permeable concrete pavement. Studies [4] have shown that the permeability coefficient of less than $15 \%$ of permeable concrete pavement is more than $50 \mathrm{~mm} / \mathrm{h}$ after running for 5-6 years without maintenance. This paper studies the attenuation laws of permeability coefficient for permeable concrete pavement under quickly plugging and slowly plugging, as well as recovery rate through high pressure gun. The results will provide theoretical basis for the design of permeable concrete pavement with anti-plugging property and promote the use of pervious concrete.

\section{Materials and procedures}

\subsection{Materials}


Cement: P.O 42.5 produced by Lafarge Cement. The physical performance of the cement used in this article is listed in Table 1.

Aggregate: Artificial broken pebbles with single grading size. The experiment has used two different sizes of coarse aggregate, and the physical performance of coarse aggregate is shown in Table 2.

Water: tap water in Chengdu.

Sand used for clogging: manufactured sand located at Chengdu, gradation: $0 \sim 0.15 \mathrm{~mm} 、 0.15 \mathrm{~mm} \sim 0.3 \mathrm{~mm}$ 、 $0.3 \mathrm{~mm} \sim 0.6 \mathrm{~mm} 、 0.6 \mathrm{~mm} \sim 1.18 \mathrm{~mm}$ and $1.18 \mathrm{~mm} \sim 2.36 \mathrm{~mm}$

\subsection{Mixture proportion and specimen preparation}

As is shown in Fig.1, two kinds of permeable concrete structure are studied in this paper, and the proportions of samples are listed in Table 3.

Table 1. Physical performance of cement.

\begin{tabular}{cccccccc}
\hline $\begin{array}{c}\text { Density } \\
\left(\mathbf{g} / \mathbf{c m}^{3}\right)\end{array}$ & $\begin{array}{c}\text { Specific } \\
\text { area } \\
\left(\mathbf{m}^{2} / \mathbf{k g}\right)\end{array}$ & \multicolumn{2}{c}{$\begin{array}{c}\text { Setting time } \\
(\mathbf{m i n})\end{array}$} & $\begin{array}{c}\text { Compressive } \\
\text { strength } \\
(\mathbf{M P a})\end{array}$ & \multicolumn{2}{c}{$\begin{array}{c}\text { Flexural } \\
\text { strength } \\
(\mathbf{M P a})\end{array}$} \\
\hline 3.11 & 374 & 145 & 540 & 27.4 & 48.9 & 5.6 & 8.1 \\
\hline
\end{tabular}

Table 2. Physical performance of coarse aggregate.

\begin{tabular}{ccc}
\hline $\begin{array}{c}\text { Particle size } \\
(\mathbf{m m})\end{array}$ & $\begin{array}{c}\text { Apparent density } \\
\left(\mathbf{k g} / \mathbf{m}^{\mathbf{3}}\right)\end{array}$ & $\begin{array}{c}\text { Packing density } \\
\left(\mathbf{k g} / \mathbf{m}^{3}\right)\end{array}$ \\
\hline $4.75-9.5$ & 2710 & 1700 \\
$9.5-16$ & 2690 & 1700 \\
\hline
\end{tabular}

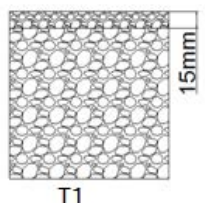

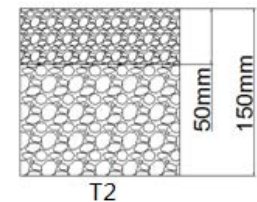

Fig. 1. Structures of permeable concrete pavement.

Table 3. Proportions of permeable concrete samples.

\begin{tabular}{cccccc}
\hline sample & $\begin{array}{c}\text { cement } \\
(\mathbf{k g})\end{array}$ & $\begin{array}{c}\text { Coarse } \\
\text { aggregate } \\
\mathbf{( k g )}\end{array}$ & $\begin{array}{c}\text { Water } \\
\text { to } \\
\text { binder } \\
\text { ratio }\end{array}$ & $\begin{array}{c}\text { Size of } \\
\text { aggregate } \\
\mathbf{( m m )}\end{array}$ & $\begin{array}{c}\text { Upper } \\
\text { crushing } \\
\text { pebble } \\
\text { thickness(mm) }\end{array}$ \\
\hline $\mathrm{T} 1$ & 400 & 1700 & 0.28 & $\begin{array}{c}4.74-9.5 \\
/ 9.5-16.0\end{array}$ & 15 \\
$\mathrm{~T} 2$ & 400 & 1700 & 0.28 & $\begin{array}{c}4.74-9.5 \\
/ 9.5-16.0\end{array}$ & 50 \\
\hline
\end{tabular}

According to literatures, [5] $7 \mathrm{mix}$ proportions of plugging materials are designed in the experiment, as is shown in table 4. A special device is used to test the permeability coefficient, as is shown in Figure.3. The water head height in this device is set to $150 \mathrm{~mm}$. After the flow is stable, adding respectively the $7 \mathrm{mix}$ proportions of plugging materials designed to 7 corresponding permeable concrete pavements samples made of the same batch, and reading the flow value every ten seconds to calculate the permeability coefficient in the following formula (1) [6-7], then potting the evolution of the permeable coefficient over time. The selection of the ideal plugging materials must consider that the results of the experiment should be evident and reasonable, so plugging materials sample 1 may be the optimal according to Fig.2. Therefore, sample 1 was used for the following quickly plugging and slowly plugging experiments.

Table 4. Plugging materials designed for permeable concrete pavement.

\begin{tabular}{cccccc}
\hline Sample & $\begin{array}{c}\mathbf{1 . 1 8}- \\
\mathbf{2 . 3 6} \mathbf{m m}(\mathbf{g})\end{array}$ & $\begin{array}{c}\mathbf{0 . 6 -} \\
\mathbf{1 . 1 8} \mathbf{m m}(\mathbf{g})\end{array}$ & $\begin{array}{c}\mathbf{0 . 3 -} \\
\mathbf{0 . 6 m m}(\mathbf{g})\end{array}$ & $\begin{array}{c}\mathbf{0 . 1 5}- \\
\mathbf{0 . 3 m m}(\mathbf{g})\end{array}$ & $\begin{array}{c}\text { Under } \\
\mathbf{0 . 1 5} \mathbf{m m}(\mathbf{g})\end{array}$ \\
\hline 1 & 0 & 5 & 10 & 10 & 5 \\
2 & 0 & 0 & 12.5 & 12.5 & 5 \\
3 & 0 & 0 & 0 & 20 & 10 \\
4 & 15 & 15 & 0 & 0 & 0 \\
5 & 6 & 12 & 12 & 0 & 0 \\
6 & 5 & 8 & 8 & 9 & 0 \\
7 & 5 & 5 & 7 & 8 & 5 \\
\hline
\end{tabular}

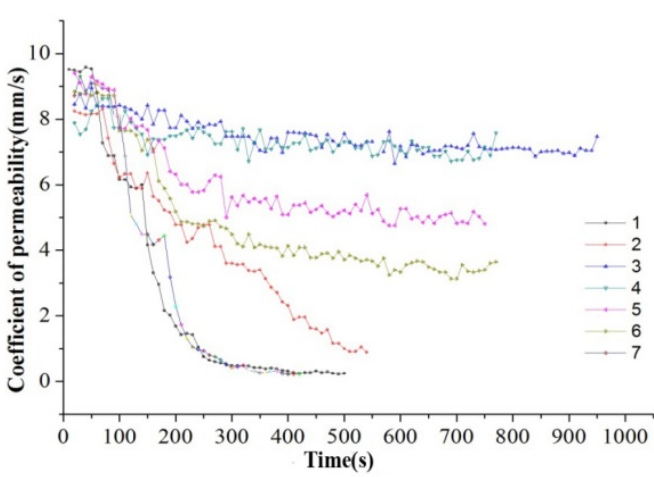

Fig. 2. Attenuation figure of permeability coefficient for permeable concrete pavement under different plugging materials.

\subsection{Experiment}

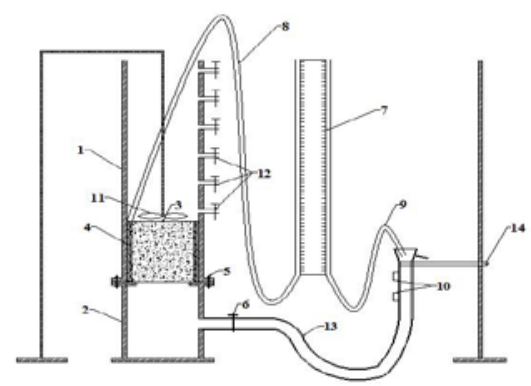

Fig. 3. Permeable coefficient measurement device.

1.Upper canister; 2.lower canister; 3.Permeable concrete pavement sample; 4.Silicone pad; 5.Bolt; 6.Valve; 7.Graduated scale; 8.Rubber hose; 9.Rubber hose; 10.Electromagnetic flow meter; 11.Propeller; 12.Valve; 13.Flexible hose; 14.Clamp.

As shown in Figure 3, a special device was made to order to test the permeability coefficient, which has been used in 2.2 above. This device includes a container, in that a permeable concrete block should be placed. The sand adder is scattered through the propeller (3). The water 
will enter the container through rubber hose (8), and then penetrates the preamble concrete into the cavity (2). Finally, it flows out of the container through flexible hose (13). The amount of water (Q) passed through the container in a certain time $(\mathrm{t})$ can be known by the graduated scale (7). So the permeability coefficient $\left(\mathrm{K}_{\mathrm{T}}\right)$ under a certain water pressure can be calculated by formula (1). And the water pressure can be adjusted by throttle valve (12).

$$
k_{T}=\frac{Q L}{A H t} \quad \text { (1) }
$$

$\mathrm{K}_{\mathrm{T}}$-Permeability coefficient at $\mathrm{T}^{\circ} \mathrm{C}(\mathrm{mm} / \mathrm{s})$; $\left(\mathrm{mm}^{3}\right)$;

$\mathrm{Q}$-The amount of water seeping out during time $\mathrm{T}$

L-Thickness of the specimens (mm);

A-Above-mentioned area of the specimens $\left(\mathrm{mm}^{2}\right)$;

$\mathrm{H}$ - Water head (mm);

t- Time (s).

The porosity is a common index to evaluate the permeability of permeable concrete. And the initial porosity of permeable concrete pavement samples can be determined by the following equation [8-9]:

$$
P=1-\left(\frac{\left(W_{2}-W_{2}\right)}{V_{2} \rho_{w}}\right) \times 100 \%
$$

$\mathrm{W}_{1}$ - Mass of samples after drying in $60^{\circ} \mathrm{C}$ oven for 24 hours, kg;

$\mathrm{W}_{2}$-Mass of samples after immersing in water for 24 hours, kg;

$\mathrm{V}_{1}$ - Value of samples, $\mathrm{mm}^{3}$;

$\rho_{\mathrm{w}}$-Density of water, $\mathrm{kg} / \mathrm{mm}^{3}$.

\section{Results and analysis}

\subsection{Measurement of porosity of permeable concrete}

The results of porosity test are shown in table 5 . The porosity value of permeable concrete $\mathrm{T} 1$ is higher than that of permeable concrete T2, because of thicker bottom layer in permeable concrete $\mathrm{T} 1$.

Table 5. Measured porosity values of permeable concrete

\begin{tabular}{ccccc}
\hline Sample & $\begin{array}{c}\text { Drying } \\
\text { mass(kg) }\end{array}$ & $\begin{array}{c}\text { Mass in } \\
\text { water(kg) }\end{array}$ & $\begin{array}{c}\text { Porosity } \\
\text { (\%) }\end{array}$ & $\begin{array}{c}\text { Average value } \\
\text { of porosity (\%) }\end{array}$ \\
\hline \multirow{3}{*}{$\mathrm{T} 1$} & 6.868 & 4.215 & 21.40 & \\
& 7.091 & 4.340 & 18.50 & 20.675 \\
& 7.035 & 4.395 & 21.80 & \\
\hline \multirow{2}{*}{$\mathrm{T} 2$} & 7.019 & 4.350 & 21.00 & \\
& 7.023 & 4.210 & 16.70 & \\
& 7.047 & 4.295 & 18.50 & \\
\hline
\end{tabular}

\subsection{Slow plugging test of permeable concrete pavement}

Plugging material $\mathrm{Z} 1$ was used in plugging test, adding $5 \mathrm{~g}$ for the interval of $1 \mathrm{~h}$, and the water head was set to be $100 \mathrm{~mm}$, without stir, to simulate the process of plugging with low speed just as normal rainfall condition. It can be seen from Fig. 4 that ladders appear in the evolution curve of the permeable coefficient during the interval of the addition of the clogging material. This phenomenon [10] can be attributed to that unsteady plugging material stuck in permeable concrete can be carried away by current, leading to a transient recovery of permeable coefficient. However, there is a limit to this recovery (Table 6).

\subsection{Quickly plugging test of permeable concrete pavement}

Plugging material Z2 was used in plugging test, adding $30 \mathrm{~g}$ for the interval of $90 \mathrm{~s}$, and the water head is set to be $100 \mathrm{~mm}$, stir at the speed of $30 \mathrm{r} / \mathrm{min}$. a numerical value would be readied from the electromagnetic flow-meter to calculate the permeability(Table 7).

Table 6. Mix design of plugging material used for slowly plugging test of permeable concrete

\begin{tabular}{ccccccc}
\hline Sample & $\begin{array}{c}\mathbf{1 . 1 8}- \\
\mathbf{2 . 3 6 m m} \\
\mathbf{( g )}\end{array}$ & $\begin{array}{c}\mathbf{1 . 1 8 m m} \\
\mathbf{( g )}\end{array}$ & $\begin{array}{c}\mathbf{0 . 6 m m} \\
\mathbf{( g )}\end{array}$ & $\begin{array}{c}\mathbf{0 . 3 m m} \\
\mathbf{( g )}\end{array}$ & $\begin{array}{c}\mathbf{0 . 1 5 m m} \\
\mathbf{( g )}\end{array}$ & $\begin{array}{c}\text { Under } \\
\text { adding } \\
\text { sand }\end{array}$ \\
\hline $\mathrm{Z} 1$ & 0 & 0.83 & 1.67 & 1.67 & 0.83 & 24 \\
\hline
\end{tabular}

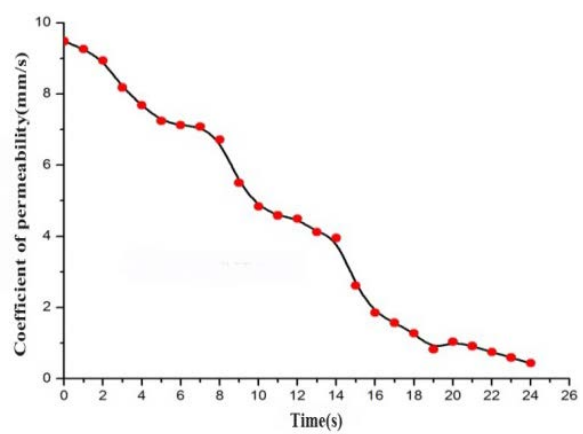

Fig. 4. Attenuation diagram of permeable concrete under slowly plugging.

It can be detected in Fig. 5 that the initial permeability coefficient for each sample is different even though the samples were made the same batch. This is because permeable concrete has a porous structure with a large internal surface area, and the manual operation error occurred when the samples formed, which the consistency of the initial coefficient of permeability could not be guaranteed even though their attenuation trends were roughly the same. When the thickness of the surface layer made of $4.74-9.5 \mathrm{~mm}$ is $15 \mathrm{~mm}$, the initial coefficient of permeability is bigger than that of $50 \mathrm{~mm}$, which is consistent with the results of the initial porosity of samples.

Compared with slowly plugging test of permeable concrete, there is no obvious that permeable coefficient recovery step on the quickly plugging attenuation diagram. This can be attributed to the short time interval of sand adding for quickly plugging test. The unstable particles could not be washed away by water after each sand addition and stayed in the permeable concrete samples together with the next time adding sand, leading to the disappearance of steps in permeability coefficient attenuation diagram and the sustained decrease of permeability coefficient for permeable concrete [11]. 
Table 7. Mix design of plugging material used for quick plugging test of permeable concrete

\begin{tabular}{ccccccc}
\hline Sample & $\begin{array}{c}\mathbf{1 . 1 8}- \\
\mathbf{2 . 3 6 m m} \\
\text { (g) }\end{array}$ & $\begin{array}{c}\mathbf{0 . 6}- \\
\mathbf{1 . 1 8 m m} \\
(\mathbf{g})\end{array}$ & $\begin{array}{c}\mathbf{0 . 6 m -} \\
\mathbf{( g )}\end{array}$ & $\begin{array}{c}\mathbf{0 . 1 5}- \\
\mathbf{0 . 3 m m} \\
(\mathbf{g})\end{array}$ & $\begin{array}{c}\text { Under } \\
\mathbf{0 . 1 5 m m} \\
(\mathbf{g})\end{array}$ & $\begin{array}{c}\text { Number } \\
\text { of times } \\
\text { adding } \\
\text { sand }\end{array}$ \\
\hline $\mathrm{Z} 2$ & 0 & 5 & 10 & 10 & 5 & 24 \\
\hline
\end{tabular}

\subsection{Recovery test of permeability coefficient of permeable concrete}

In recent years, many researchers [12] have studied the recovery of permeability coefficient of permeable concrete pavement. The main measures for improving the permeability of permeable concrete are broom sweeping, high pressure water guan washing and vacuum suction etc. After the comparing of several maintenance measures for permeable concrete pavement, researchers [13] point out that the high pressure gun is more effective than other measures. In this paper, the permeability coefficients of permeable concrete samples are restored by high pressure gun to study the recovery rate of the two permeable concrete pavements.

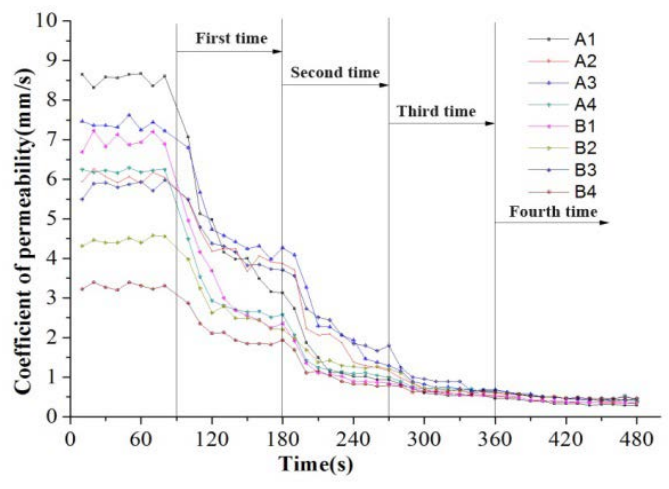

Fig. 5. Attenuation diagram of permeable concrete under quickly plugging.

The recover values and recovery rates of the samples are shown in Table 8 after the first restore with high pressure gun. From the table data, the recovery capacity of permeable concrete samples whose upper layer is $15 \mathrm{~mm}$ is better than that of $50 \mathrm{~mm}$ by $10 \%$. This can be explained by that the thinner the size of the upper layer made of $4.74-9.5 \mathrm{~mm}$ artificially broken pebbles, the easier to be washed out by high pressure gun.

Table 8. Recovery rate of permeable concrete under high pressure gun

\begin{tabular}{ccccc}
\hline \multicolumn{2}{c}{ Sample } & $\mathbf{P}_{\mathbf{l}}(\mathbf{~ m m} / \mathbf{s})$ & $\mathbf{P}_{\mathbf{F}}(\mathbf{m m} / \mathbf{s})$ & $\mathbf{P}_{\mathbf{( \% )}}$ \\
\hline \multirow{4}{*}{ A } & A1 & 8.544 & 7.141 & 83.58 \\
& A2 & 6.044 & 4.968 & 82.20 \\
& A3 & 7.378 & 6.003 & 81.36 \\
& A4 & 8.094 & 6.748 & 83.37 \\
B & B1 & 6.969 & 4.716 & 67.67 \\
& B2 & 4.453 & 3.541 & 79.52 \\
& B3 & 5.822 & 4.506 & 77.40 \\
\hline
\end{tabular}

$\mathrm{P}_{1}$-Initial coefficient of permeability;

$\mathrm{P}_{\mathrm{F}}$-Coefficient of permeability after primarily recovered test;

$\rho$ - Degree of recovery, $\rho=\left(\mathrm{P}_{1} / \mathrm{P}_{\mathrm{T}}\right) \times 100 \%$
Table 9 shows the recovery and the permeable coefficients of samples after repeated plugging test. Based on the data in Table 8, the recovery rate of permeable concrete samples with $15 \mathrm{~mm}$ upper layer are better than those blocks whose upper layer thickness are $50 \mathrm{~mm}$. This theoretically shows that reasonable thickness of the upper layer of the permeable concrete, to some extent, will be benefit to the recovery of the permeability coefficient of permeable concrete pavement, and prolong the life of the permeable concrete pavement.

Table 9. Recovery of permeable concrete sample after repeated plugging test

\begin{tabular}{cccccc}
\hline $\mathbf{h}(\mathbf{m m})$ & $\mathbf{P}_{\mathbf{l}}(\mathbf{m m} / \mathbf{s})$ & $\mathbf{P}_{\mathbf{F}}(\mathbf{m m} / \mathbf{s})$ & $\mathbf{P}_{\mathbf{S}}(\mathbf{m m} / \mathbf{s})$ & $\mathbf{P}_{\mathbf{T}}(\mathbf{m m} / \mathbf{s})$ & $\mathbf{P}_{\mathbf{( \% )}}$ \\
\hline 15 & 7.38 & 6.00 & 5.05 & 5.66 & 76.7 \\
50 & 6.22 & 3.84 & 3.39 & 2.75 & 44.2 \\
\hline
\end{tabular}

h- Thickness of upper layer;

$\mathrm{P}_{1}$-Initial coefficient of permeability;

$\mathrm{P}_{\mathrm{F}}$-Coefficient of permeability after primarily recovered test;

$\mathrm{P}_{\mathrm{S}}$ - Coefficient of permeability after second recovered test;

$\mathrm{P}_{\mathrm{T}}$ - Coefficient of permeability after third recovered test;

$\rho$ - Degree of recovery, $\rho=\left(\mathrm{P}_{1} / \mathrm{P}_{\mathrm{T}}\right) \times 100 \%$

\section{Conclusion}

a) When the unit weight of the samples are same, the thinner the size of the upper layer, the larger the porosity of permeable concrete samples;

b) Due to artificial molding, initial coefficients of permeability of samples are different. The thinner the size of the upper layer is, the larger the initial permeable coefficient will be, and the higher recovery rate the permeable coefficient will have after plugging tests;

c) Steps on the attenuation diagram of permeable concrete fall slowly under slowly plugging test because of sustained flow, while there have fast attenuation rates on the permeable coefficient attenuation diagram;

d) Reasonable thickness of the upper layer will postpone the plugging and prolong the life of permeable concrete pavement, and the upper structure of $15 \mathrm{~mm}$ would be a priority selection.

\section{References}

1. ZOU R, ZHOU W J, and LI X Y, "The generation and research method of urban heat island effect," Rural Economy and science technology, vol. 18, pp.107-113, March 2007.(In Chinese)

2. SIRIWARDENE $\mathrm{N}$ R, DELETIC $\mathrm{A}$, and FLETCHER TD., "Clogging of storm-water gravel infiltration systems and filters: insights from a laboratory study,” Water Research, vol 41, pp.14331440, July 2007.

3. TAN S, FWA $\mathrm{T} \mathrm{F}$, and HAN C T, "Clogging evaluation of permeable bases ," Journal of transportation engineering, vol 129, pp.309-315, March 2003.

4. Drake J, Bradford A, and Seters T V, "Hydrologic performance of three partial-infiltration permeable pavements in a cold climate over low permeability 
soil,” Journal of Hydrologic Engineering, vol 19, pp.159-169, September 2014.

5. LIU Y Y, JIANG C, LIU J, LIU H, WU Y X, and ZHAO J H, "Advances on the research of plugging and recovery of permeable concrete pavement," Environment Science \&Technology, vol 39, pp.159163, May 2016.

6. Tennis Paul D, Liming Michael L., and Akers David J., Pervious concrete pavements, Skokie, IL: Portland Cement Association, 2004.

7. Hendricks IL, Noiseless concrete pavements, Retrieved from http://www.eupave.edu/documents/graphics/inventor y-of-

documents/febelcempublicaties/noiselessconcretepavements.pdf, 1998.

8. Crouch LK, Cates MA, Dotson VJ, Honeycutt KR, and Badoe D, "Measuring the effective air void content of Portland cement pervious pavements," Cen Concr Aggr, vol 25, pp.16-20, January 2003.

9. MONTES F, VALAVALA S, and HASELBACH L, "A new test method for porosity measurements of
Portland cement pervious concrete," Journal of ASTM International, vol 2, pp.1-13, February 2005.

10. ZHENG M L, WANG B G, and HU C S, "Study on fatigue properties of permeable concrete ,” Journal of Chinese highway, vol 17, pp.7-11, January 2004.(In Chinese)

11. CUI X Z, ZHANG J, HUANG D, JIN Q, and HOU $\mathrm{F}$, "Simulation of the rapid plugging test of permeable concrete pavement under heavy rain,” vol 29, pp.1-19, October 2016.

12. Henderson V, and Tighe S L, "Evaluation of pervious concrete pavement permeability renewal maintenance methods at field sites in Canada ," Canadian Journal of Civil Engineering, vol 38, pp.1404-1413, December 2011.

13. Chopra M, Kakuturu S, and Ballock C, "Effect of rejuvenation methods on the infiltration rates of pervious concrete pavements," Journal of Hydrologic Engineering, vol 112, pp.426-433, June 2010. 